\title{
ЗД-15
}

\section{СРАВНЕНИЕ ВОЗМОЖНОСТЕЙ СОВРЕМЕННОГО АНАЛИТИЧЕСКОГО ОБОРУДОВАНИЯ ДЛЯ РЕНТГЕНОСПЕКТРАЛЬНОГО АНАЛИЗА}

\author{
Денисов С.П., Бубнов К.В., Мельникова Н.В. \\ ООО «Экоальянс», Новоуральск, Россия \\ melnik321@ya.ru
}

DOI: 10.26902/ASFE-11_153

С 1994 года ООО «Экоальянс» использует ренгенофлуоресцентные спектрометры для контроля технологического процесса и готовой продукции производства каталитических блоков нейтрализаторов выхлопных газов.

С целью приобретения нового спектрометра были изучены возможности современного аналитического оборудования для рентгеноспектрального анализа. В результате переговоров со специалистами ООО «Термо Техно Инжиниринг», ООО «Мелитэк», фирмы «Солисте Корпорэйшн», ООО «Спектрис Си-Ай-Эс», компании «Элемент», было получено разрешение провести измерения наших образцов на эксплуатируемых в России приборах, организованы поездки специалистов ООО «Экоальянс» на предприятия в городах Нижний Тагил, Челябинск, Полевской, Верхняя Пышма, Красноярск, Екатеринбург. Исследования идентичных образцов были проведены в одинаковых условиях на следующих спектрометрах:

- ARL PERFORM'X, изготовитель «Thermo Fisher Scientific» (Ecublens) SARL», Швейцария;

- $\quad$ S8 TIGER, изготовитель «BRUKER AXS GmbH», Германия;

- $\quad$ ZSX Primus II, изготовитель «Rigaku Corporation», Япония;

- $\quad$ Zetium, изготовитель «PANalytical B.V.», Нидерланды;

- $\quad$ XRF-1800, изготовитель «Shimadzu Corporation»», Япония.

B докладе представлены данные, подтверждающие приемлемость перечисленных спектрометров для решения задач нашего предприятия и новые возможности современного оборудования, по сравнению с 1994 годом. 